\title{
INFORMES:
}

\section{CHARTA MUNDATORIA}

chama-se agora nosso conhecido "papel-higiênico".

Prof. Oswaldo O. Portella

Titular de Lingua Latina da U.F.P.

Constituiu-se na Europa um grupo de lingüistas, de diversos países, não excluído o bloco soviético, cujo propósito principal é o de cultivar e restaurar a Latinidade Viva no mundo, tornando a língua latina o idioma de comunicação universal e a segunda lingua a ser ensinada em cada país, ao lado da vernácula.

A sede desta singular sociedade é a Universidade de Saarbrücken, na Alemanha. Os neolatinistas, como se chamam, conquanto nāo formem ainda um grupo muito numeroso, são todavia uma minoria atuante e bastante radical. No último congresso realizado em Dakar, capital do Senegal, por esta sociedade, para promover a Latinidade Viva, reuniram-se cerca de 500 participantes de todas as partes do mundo, sob a presidência de honra do primeiro mandatário do pais, poeta, escritor e latinista renomado, Leopoldo Sédar Senghor.

Ocupa a presidência da sociedade atualmente o $\mathrm{Dr} . \mathrm{P}$. Caelestis Eichenseer, da Universidade de Saarbrücken, que também dirige e edita a revista oficial da sociedade - VOX LATINA. Esta revista, que vem sendo editada desde 1956, recebe a colaboração de eminentes professores de diversas universidade européias.

O lema da sociedade é - LATINITATEM COLAMUS, port. Cultivemos a Latinidade. Os neolatinistas estão firmemente convictos de que a língua latina é a única com capacidade de solver as pendências lingüisticas entre os países e também a única com possibilidades de se tornar a lingua de comunicação universal. Contra o Esperanto, lingua formada para esta finalidade, existe o inconveniente de ser uma língua 
artificial, portanto sem lastro cultural suficiente. Latim, ao contrário, afirmam os neolatinistas, não somente teve um passado glorioso mas terá um futuro auspicioso pois é a única língua do mundo que não exige de nenhum povo o sacrifício da consciência nacional. Por outro lado, os constantes conflitos linguiisticos entre os povos estão a reclamar uma lingua neutra, portanto apolítica, e de livre trânsito em todo o mundo. Os organismos internacionais como a ONU, UNESCO, FAU e a Sociedade Européia de Comércio são os que mais se ressentem da ausência de uma língua comum, não só para os debates em plenário como também e, principalmente, para a redação dos documentos oficiais.

A língua da antiga Roma, afirmam os neolatinistas, tem todas as qualidades necessárias para se tornar este idioma comum: vasto back-ground histórico, cultural e científico além de completamente neutra por nāo ser falada hodiernamente per nenhum povo em particular, apesar de ser a língua mãe de todas as linguas novilatinas, não excluído o inglês que possui mais de $50 \%$ de palavras de radical latino. Merece ser lembrado ainda o fato de o latim continuar sendo a língua das nomenclaturas cientificas de zoologia, botânica, as. tronomia, etc.

Exemplo de litigio lingüistico é o que ocorreu recentemente com o Passaporte Europeu, passaporte comum, válido para todos os paises europeus, que se está tentando implantar. Até hoje não foi possivel emiti-lo, apesar de aprovado, porque não se chegou a um acordo sobre a língua ou em que série de línguas devem vir grafados os dizeres. Em vez de em inglês, francês, alemão, espanhol ou nestas línguas na ordem inversa de preferência, muito mais econômico e pacifico, afirmam os neolatinistas, será grafar somente em latim as instruções e os dados pessoais: Nomen. .., Praenomen....., Locus natalis . ......., Magnitudo . ....., Oculorum color.........., etc.

Outro exemplo de litigio lingüistico é o que se passa dentro dos plenários da Sociedade Européia de Comércio onde se sentam, lado a lado, delegados de paises que há séculos mantèm acirrada rivalidade, não só politica mas também lingüística, em que esta última vem sendo causa e pretexto para constantes desentendimentos. O mesmo acontece nas reuniões da $\mathrm{ONU}$, organismo em que até a China reivindicou e conseguiu o reconhecimento de sua língua, dificultando a comunicação e encarecendo a impressão dos documentos oficiais por causa das características da escrita chinesa. $\mathbf{E}$ as dificuldades lingüisticas da ONU tendem a crescer com a admissāo de muitos países novos, não sendo surpresa se logo 
os paises árabes estiverem reivindicando o mesmo direito dos chineses, respaldados em seus petro-dólares.

Uma língua comum, especificamente o latim, por suas qualidades acima apontadas, resolveria satisfatoriamente o problema, como vem resolvendo há séculos o problema linguiistico do Estado do Vaticano.

Nem é válida a alegaçāo daqueles que afirmam que 0 latim é uma língua que parou no tempo e portanto inapta para exprimir os conceitos cientificos e culturais modernos. Como já foi dito acima, a terminologia científica nunca prescindiu do latim. Existem acordos internacionais para a manutenção da nomenclatura científica em todos os ramos. $O$ caso mais recente, de nosso conlecimento, é o acordo científico da União Internacional de Astronomia pelo qual os paises signatários se obrigam a adotar a nomenclatura latina nas pesquisas espaciais. Obedecendo a este acordo, a NASA publicou o seu MAPA DA LUA, em que os topônimos lunares vêm escritos em latim. Mare Crisium, Mare Fecunditatis, Mare Frigoris, Oceanus Procellarum, Lacus Somniorum, Palus Putredinis, Sinus Iridium, Rupes Recta, Rima Hyâginus, Vallis Alpes, Mons Taurus são alguns dentre centenas de topônimos lunares.

E para provar a propriedade do latim como meio de comunicação moderno, os neolatinistas traduzem para a língua de Cícero vários acordos comerciais europeus, bem como comentam em latim fatos políticos da atualidade. Entre os neolatinistas existem alguns técnicos em criar e traduzir para o latim vocábulos modernos, que os antigos romanos certamente não conheceram. Eis uma pequena relação:

$\begin{array}{ll}\text { Papel higiênico } & - \text { Charta mundatoria } \\ \text { Máq. de calcular } & - \text { Machina calculatoria } \\ \text { Computador } & -\quad \text { Instrumentum computatorium } \\ \text { Cooperativa } & - \text { Societas cooperativa } \\ \text { Gangster } & - \text { Praerlo gregalis } \\ \text { Eisberg } & - \text { Mons glaciatus } \\ \text { Rugby } & - \text { Scalae milae ludus } \\ \text { Escada rolante } & - \text { Aeroportus, aerodromus } \\ \text { Aeroporto } & - \text { Celcissimae aedes } \\ \text { Arranha-céu } & - \text { Autoraeda } \\ \text { Automóvel } & - \text { Aeroplanum } \\ \text { Avião } & - \text { Barbam radens machinula } \\ \text { Barbeador elétrico } & - \text { Bicycla } \\ \text { Bicicleta } & - \text { Pyrobolum } \\ \text { Bomba } & - \text { Tabaci fistula } \\ \text { Cigarro } & \end{array}$


Cinema

Despertador

Geladeira

Futebol

Goleiro

Gol

Centro-avante

Ponta-direita

Jazz
- Cinematographum

- Horologium expergefaciens

- Frigidarium

- Ludopedium

- Janitor

- Meta

- Assuitor centralis

- Extremus dexter

- Absurda symphonia

Como se observa, não existe problema em atualizar a lingua latina, de modo que ela possa se tornar aquele veículo de comunicação, de que o mundo dividido e conturbado de hoje está necessitando. 